\title{
Combine Effect of Exhaust Gas Recirculation (EGR) and Varying Inlet Air Pressure on Performance and Emission of Diesel Engine
}

\author{
Mr. Harshraj Dangar ${ }^{1}$, Prof. Gaurav P. Rathod ${ }^{2}$ \\ ${ }^{I}$ ME Student, L.D.R.P Engineering College, Gandhinagar, India. \\ ${ }^{2}$ Asst. Prof. in L.D.R.P Engineering College, Gandhinagar, India.
}

\begin{abstract}
To meet stringent vehicular exhaust emission norms worldwide, several exhaust pre-treatment and post treatment techniques have been employed in modern engines. Also concern of environmental pollution and energy crisis all over the world have caused the research attention on reduction of diesel engine exhaust emissions and saving of energy simultaneously. This investigation mainly focuses on reducing exhaust emission and energy saving by investigating diesel combustion with neat diesel fuel and a new attachment of pressurized inlet air with Exhaust Gas Recirculation (EGR) system. Experiment was conducted in a four stroke direct injection water cooled constant speed diesel engine with pressurize inlet air attachment and EGR system, which is typically used in agricultural farm machinery. EGR was applied to the experimental engine separately and also with varying pressure of inlet air. In this study, compressor was used to pressurize the inlet air. The experiments were carried out to experimentally evaluate the performance and emissions for combine effect different EGR rates and varying inlet air pressure of the engine. Emissions of hydrocarbon (HC), NOx, carbon monoxide $(\mathrm{CO})$, carbon dioxide $\left(\mathrm{CO}_{2}\right)$ and temperature of the exhaust gas were measured. Performance parameters such as Brake thermal efficiency, brake specific fuel consumption (BSFC) were calculated. It was found that combined effect of pressurize inlet air attachment and EGR system provided better result on engine performance than individual EGR effect. Reductions in NOx and exhaust gas temperature were observed but emissions of $\mathrm{HC}, \mathrm{CO}$ and $\mathrm{CO}_{2}$ were found to have increased with combine usage of EGR and inlet air pressure. Thus the modified engine provides more NOx reduction and better fuel economy without reducing useful characteristics (brake power, brake thermal efficiency etc) of the engine.
\end{abstract}

Keyword: Diesel engine, Emission, Exhaust gas recirculation, Inlet air pressure, NOx.

\section{Introduction}

Better fuel economy and higher power with lower maintenance cost has increased the popularity of diesel engine vehicles. Diesel engines have inherently high thermal efficiencies, resulting from their high compression ratio and fuel lean operation. The high compression ratio produces the high temperatures required to achieve auto-ignition, and the resulting high expansion ratio makes the engine discharge less thermal energy in the exhaust. The extra oxygen in the cylinders is necessary to facilitate complete combustion and to compensate for non-homogeneity in the fuel distribution. However, high flame temperatures predominate because locally stoichiometric air-fuel ratios prevail in such heterogeneous combustion processes [11]. Consequently, Diesel engine combustion generates large amounts of NOx because of the high flame temperature in the presence of abundant oxygen and nitrogen [6,7]. NOx comprise of nitric oxide (NO) and nitrogen dioxide $\left(\mathrm{NO}_{2}\right)$ and both are considered to be deleterious to humans as well as environmental health. $\mathrm{NO}_{2}$ is considered to be more toxic than NO. It affects human health directly and is precursor to ozone formation, which is mainly responsible for smog formation. The ratio of $\mathrm{NO}_{2}$ and $\mathrm{NO}$ in diesel engine exhaust is quite small, but $\mathrm{NO}$ gets quickly oxidized in the environment, forming $\mathrm{NO}_{2}$. Since diesel engine mainly emits $\mathrm{NO}$ hence attention has been given to reduce the NO formation [3].

Diesel engines are used for bulk movement of goods, powering stationary/mobile equipment, and to generate electricity more economically than any other device in this size range. In most of the global car markets, record diesel car sales have been observed in recent years [1]. The exhorting anticipation of additional improvements in diesel fuel and diesel vehicle sales in future have forced diesel engine manufacturers to upgrade the technology in terms of power, fuel economy and emissions. Diesel emissions are categorized as carcinogenic [2]. Also the stringent emission legislations are compelling engine manufacturers to develop technologies to combat exhaust emissions. To meet these emission regulations with competitive fuel economy, exhaust gas after-treatment and optimized combustion are necessary. In fact, partial recirculation of exhaust gas, which is not a new technique and also well-established technology for NOx reduciton, has recently become essential, in combination with other techniques, for attaining lower emission levels [18]. 


\section{NOx Formation Mechanism}

A major hurdle in understanding the mechanism of formation and controlling NOx emission is that combustion is highly heterogeneous and transient in diesel engines.

While $\mathrm{NO}$ and $\mathrm{NO}_{2}$ are lumped together as NOx, there are some distinctive differences between these two pollutants. $\mathrm{NO}$ is a colourless and odourless gas, while $\mathrm{NO}_{2}$ is a reddish brown gas with pungent odour. Both gases are considered as toxic; butNO $\mathrm{N}_{2}$ has a level of toxicity 5 times greater than that of NO. Although $\mathrm{NO}_{2}$ is largely formed from oxidation of $\mathrm{NO}$, attention has been given on how $\mathrm{NO}$ can be controlled before and after combustion [3].

NO is formed during the post flame combustion process in a high temperature region. The most widely accepted mechanism was suggested by Zeldovich [19]. The principal source of NO formation is the oxidation of the nitrogen present in atmospheric air. The nitric oxide formation chain reactions are initiated by atomic oxygen, which forms from the dissociation of oxygen molecules at the high temperatures reached during the combustion process. The principal reactions governing the formation of $\mathrm{NO}$ from molecular nitrogen are,

$$
\begin{aligned}
\mathrm{N}_{2}+\mathrm{O} & \rightarrow \mathrm{NO}+\mathrm{N}, \\
\mathrm{N}+\mathrm{O}_{2} & \rightarrow \mathrm{NO}+\mathrm{O}, \\
\mathrm{N}+\mathrm{OH} & \rightarrow \mathrm{NO}+\mathrm{H} .
\end{aligned}
$$

In diesel engine $\mathrm{NO}_{2}$ can be 10 to $30 \%$ of total exhaust emissions of oxides of nitrogen. A plausible mechanism for the persistence of $\mathrm{NO}_{2}$ is as follows. $\mathrm{NO}$ formed in the flame zone can be rapidly converted to $\mathrm{NO}_{2}$ via reactions such as

Subsequently, conversion of this $\mathrm{NO}_{2}$ to $\mathrm{NO}$ occurs via

$$
\mathrm{NO}+\mathrm{HO}_{2} \rightarrow \mathrm{NO}_{2}+\mathrm{OH} \text {. }
$$

$$
\mathrm{NO}_{2}+\mathrm{O} \rightarrow \mathrm{NO}+\mathrm{O}_{2}
$$

unless the $\mathrm{NO}_{2}$ formed in the flame is quenched by mixing with cooler fluid. This explanation is consistent with the highest $\mathrm{NO}_{2}=\mathrm{NO}$ ratio occurring at high load in diesels, when cooler regions which could quench the conversion back to $\mathrm{NO}$ are widespread [12].

\section{Exhaust Gas Recirculation:}

Exhaust Gas Recirculation (EGR) is an effective pretreatment technique, which is being used widely to reduce and control the oxides of nitrogen (NOx) emission from diesel engines. Exhaust gas recycle is done by ducting some of the exhaust flow back into the intake system (shown in Fig. 3.1), usually immediately after the throttle. EGR combines with exhaust residual left in the cylinder from the previous cycle to effectively reduce the maximum combustion temperature.

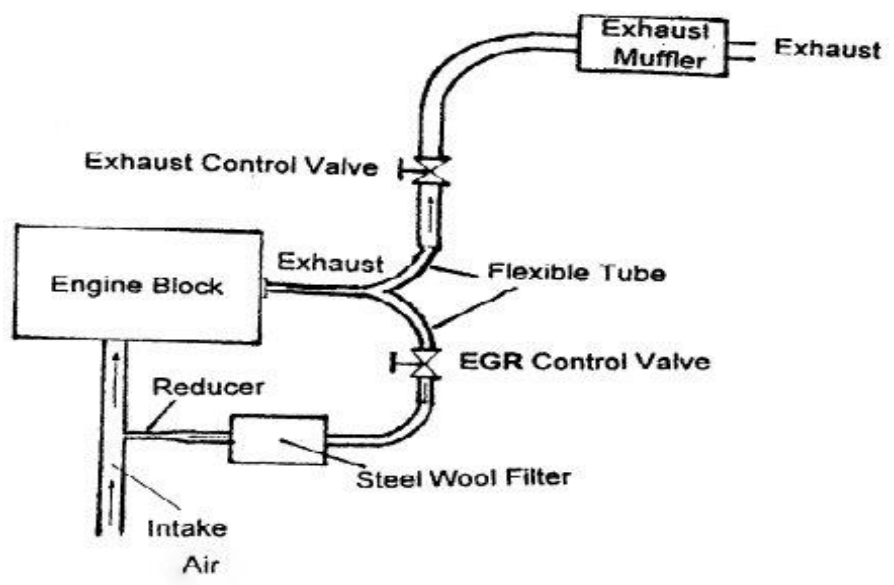

Figure 3.1: EGR system

The exhaust gas acts as an inert gas in the combustion chamber, it does not participate in the combustion reaction. This leads to a reduction of the combustion temperature by different effects. The fuel molecules need more time to find an oxygen molecule to react with, as there are inert molecules around. This slows down the combustion speed and thus reduces the peak combustion temperature, as the same amount of energy is released over a longer period of time. This causes a correspondingly lower heat release and peak cylinder temperature, and reduces the formation of $\mathrm{NO}_{\mathrm{x}}$. The presence of an inert gas in the cylinder further limits the peak temperature (more than throttling alone in a spark ignition engine) [4]. The amount of flow can be as high as 30\% of the total intake. The flow rate of EGR is controlled by the Engine Management System. A valve is usually used to control the flow of gas, and the valve may be closed completely if required. 
Jaffar Hussain et al have been carried out an experiment to investigate the effect of EGR on performance and emissions in a three cylinders, air cooled and constant speed direct injection diesel engine. They mainly focus on different EGR rate. They were measured the emission of hydrocarbons (HC), NOx, carbon monoxide (CO), exhaust gas temperature, and smoke opacity and also calculated the performance parameter such as thermal efficiency and brake specific fuel consumption (BSFC). They concluded that thermal efficiency is slightly decreased and BSFC is increased with EGR compared to without EGR. Exhaust gas temperature is decreased with EGR, but NOx emission decreases significantly. They observed that $15 \%$ EGR rate is found to be effective to reduce NOx emission substantially without deteriorating engine performance in terms of thermal efficiency, BSFC, and emissions. EGR can be applied to diesel engine without sacrificing its efficiency and fuel economy and NOx reduction can thus be achieved. The increase in CO, HC, and PM emissions can be reduced by using exhaust after-treatment techniques, such as diesel oxidation catalysts (DOCs) and soot traps [18].

Wagner et al. tried to achieve lower emission of NOx and soot using highly diluted intake mixture. At very high EGR rate (around 44\%), PM emission decreased sharply with a continuous drop in NOx emission but this high EGR rate significantly affect the fuel economy [12]. Sasaki et al. conducted experiments using EGR on direct injection gasoline engine and reported that an appropriate volume of EGR improves fuel economy and $\mathrm{HC}$ emissions. This phenomenon was presumably due to the intake temperature increase by EGR, which improved the flame propagation in the relatively lean region of the air-fuel mixture, which is non-uniformly distributed [5]. Buomsik Shin et al in their experiment, hydrogen were added into the intake manifold of a diesel engine to investigate its effect on NOx emissions and thermal efficiency under low-temperature and heavy-EGR conditions. They obtained Lower NOx emissions by supplying hydrogen at a constant EGR ratio. The percentage NOx reduction due to the hydrogen was greater at higher EGR ratios. At a $31 \%$ EGR ratio, the specific NOx was lowered by $25 \%$ when the hydrogen equivalent to $10 \%$ of the total fuel's lower heating value was supplied, compared with pure diesel combustion. They also observed the brake thermal efficiency, calculated from the torque and fuel flow rate measurements, improved slightly due to the hydrogen supply, even at low intake gas temperatures and heavy-EGR conditions [9].

Nidal H. Abu-Hamdeh in his experiment were designed spiral fin exhaust pipes to study the effect of cooling the recirculated exhaust gases (EGR) of Diesel engines on the chemical composition of the exhaust gases and the reduction in the percentages of pollutant emissions. He found that $\mathrm{O} 2$ and $\mathrm{CO} 2$ concentration in exhaust gases decreased but $\mathrm{CO}$ percentage in the exhaust gases increased because of using the heat exchanger pipes. The exhaust NOx was decreased and particulate matter concentrations were increased as a result of increasing the cooled EGR ratios [10].

Rizalman Mamat et al conducted an experiment on Ultra Low Sulphur Diesel (ULSD) and finds effect of Air Inlet Pressure drop on Performance and emission. They concluded that increase of pressure drop resulted to increase BSFC and reduce the engine efficiency at low load and part load. The exhaust emission of NOx is increase as pressure drop increase [16]. Mustafa Canakci have been conducted an experiment to study the effects of boost pressure on the performance and exhaust emissions of a DI-HCCI gasoline engine. He finds that Brake Thermal Efficiency increases with increase of Fuel consumption. CO, HC increases with increase of Inlet Pressure while NOx reduces [15].

\section{Experimental Setup Description}

A single-cylinder, 4-stroke, direct injection water-cooled diesel engine of $5 \mathrm{hp}$ rated power is considered to study the combine effect of EGR and varying inlet air pressure on the performance and emissions of engine. The engine is coupled with a rope brake dynamometer through a load cell. It is integrated with a data acquisition system to store the data for the offline analysis. A pipe arrangement was established for recirculation of exhaust gas from engine. Two manually operated valves are provided in the exhaust gas circuit to get the desired mass flow rate of exhaust gas. Asbestos insulation was provided on the exhaust pipe line therefore not allowing the recirculated exhaust gases to cool down. The schematic layout of the experimental set up is shown in below Fig. 4.1. 


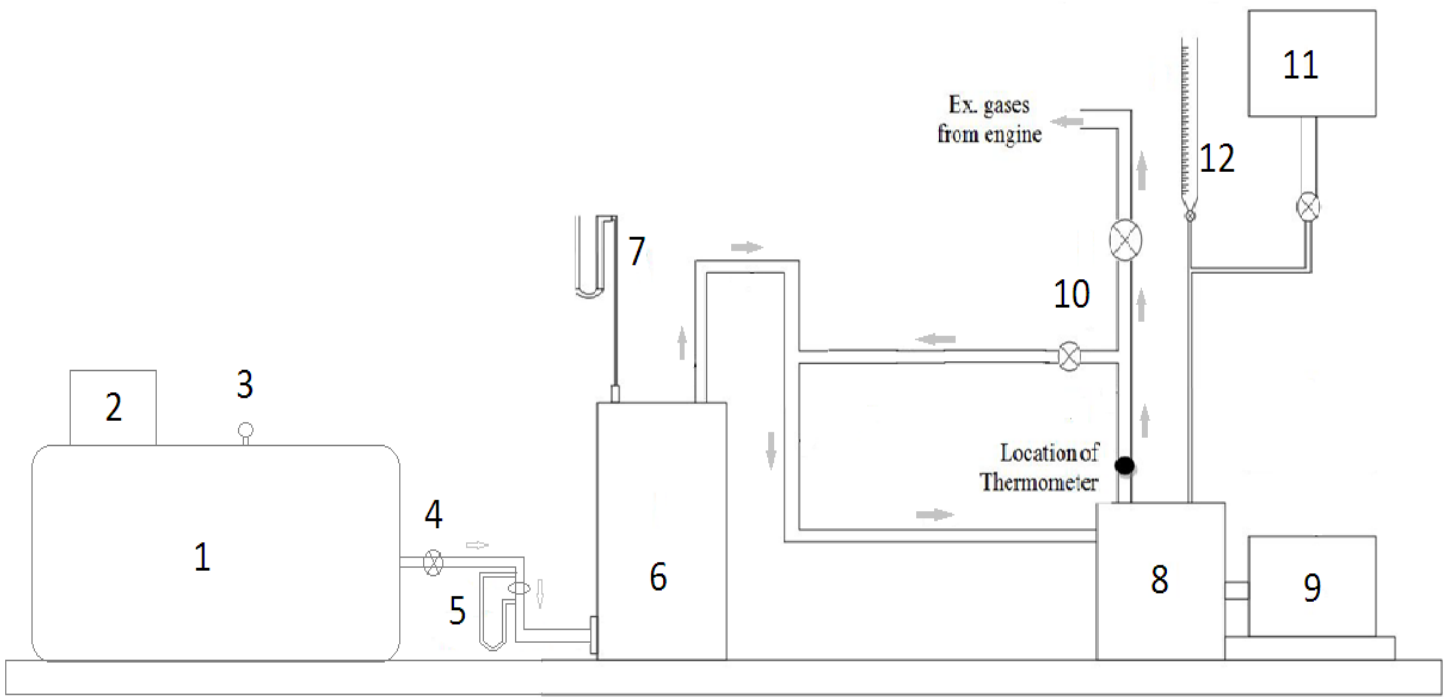

1. Two stage reciprocating air compressor, 2. Compressor motor, 3. Pressure gauge, 4. Compressor discharge valve, 5. Orifice plate connected with U-tube manometer, 6. Surge tank, 7. U-tube manometer, 8. Diesel engine, 9. Rope brake dynamometer, 10. EGR regulating valve, 11. Fuel tank, 12. Burette for the fuel flow measurement.

Figure 4.1 Schematic diagram of Engine setup.

Table 4.1 Engine Specification

\begin{tabular}{|l|l|}
\hline Parameter & Detail \\
\hline Engine & Single cylinder high speed DI diesel engine \\
\hline Cooling & Water cooled \\
\hline Bore x stroke & $80 \mathrm{~mm}$ x $110 \mathrm{~mm}$ \\
\hline Compression ratio & $16: 1$ \\
\hline Maximum power & $5 \mathrm{hp}$ or $3.7 \mathrm{kw}$ \\
\hline Rated speed & $1500 \mathrm{rpm}$ \\
\hline Capacity & $553 \mathrm{CC}$ \\
\hline
\end{tabular}

The specifications of stationary $5 \mathrm{hp}$ direct injection diesel engine used to conduct experiments are given in Table 4.1. In this experiment, a two stage reciprocating air compressor was used to pressurize the inlet air. An air tank connected with pressure gauge was provided in suction pipe to dampen the fluctuations of the pulsating inlet air. Air at the inlet was monitor using compressor, air tank, pressure gauge and valve arrangement. An orifice plate connected with U-tube manometer was installed in the suction circuit to measure the flow rate of inlet air. Temperature sensor was used to measure the exhaust gas temperature. Concentration of $\mathrm{NOx}, \mathrm{CO}, \mathrm{CO} 2$ and $\mathrm{HC}$ measurement were done by using gas analyzer. The percentage of exhaust gas recirculation (EGR (\%)) is calculated as the percentage of the total intake mixture which is recycled exhaust,

$$
\operatorname{EGR}(\%)=\left(\mathrm{m}_{\mathrm{EGR}} / \mathrm{m}_{\mathrm{i}}\right) * 100
$$

Where, $\mathrm{m}_{\mathrm{i}}=\mathrm{m}_{\mathrm{a}}+\mathrm{m}_{\mathrm{f}}+\mathrm{m}_{\mathrm{EGR}}$

$\left(\mathrm{m}_{\mathrm{i}}=\right.$ mass of total intake, $\mathrm{m}_{\mathrm{a}}=$ mass of air, $\mathrm{m}_{\mathrm{f}}=$ mass of fuel and $\mathrm{m}_{\mathrm{EGR}}=$ mass of EGR $)$

To achieve the objectives of the study, first the experiment was carried out for conventional diesel engine with different rates of EGR at atmospheric inlet air pressure. For experiment three different EGR rates $5 \%, 10 \%$ and $15 \%$ respectively were selected. Than after the experiment was carried out for varying inlet air pressure with same different EGR rates and calculate the combine effect of both on engine performance and emission. The three ranges of inlet air pressure $100 \mathrm{kPa}, 120 \mathrm{kPa}$ and $140 \mathrm{kPa}$ were selected. The data for $\mathrm{HC}$, $\mathrm{NOx}, \mathrm{CO}, \mathrm{CO}_{2}$, exhaust gas temperature, and fuel consumption were recorded. Then, engine performance and emission patterns were compared. 


\section{Results And Discussion}

The engine was run on different loads condition at $1500 \mathrm{rpm}$ with different EGR rates $(0 \%, 5 \%, 10 \%$ and $15 \%)$ and different inlet air pressure $(100 \mathrm{kPa}, 120 \mathrm{kPa}$ and $140 \mathrm{kPa})$ to investigate the effect of EGR on engine performance and emissions. The performance and emission data was analyzed and presented graphically for thermal efficiency, BSFC, exhaust gas temperature, $\mathrm{NOx}, \mathrm{HC}, \mathrm{CO}$ and $\mathrm{CO}_{2}$ emission.

\subsection{Engine Performance Analysis}

The trends of Brake thermal efficiency for different load condition are shown in Fig. 5.1 (a) and (b). The brake thermal efficiency is calculated by dividing the actual brake work to the amount of fuel energy input. Brake thermal efficiency is found to have decreased with increasing rates of EGR but with increasing inlet air pressure the brake thermal efficiency is increased. The possible reason may be with increasing in EGR rates, exhaust gas has higher amount of $\mathrm{CO}_{2}$, which reduces maximum temperature in combustion chamber along with oxygen availability therefore burning of fuel is not significant but with increasing inlet air pressure along with EGR it increase oxygen availability and significantly burning of fuel is occurred.

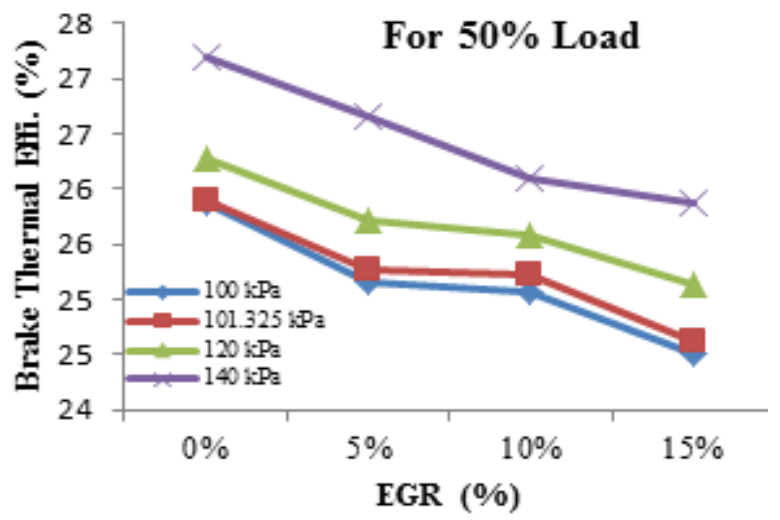

(a)

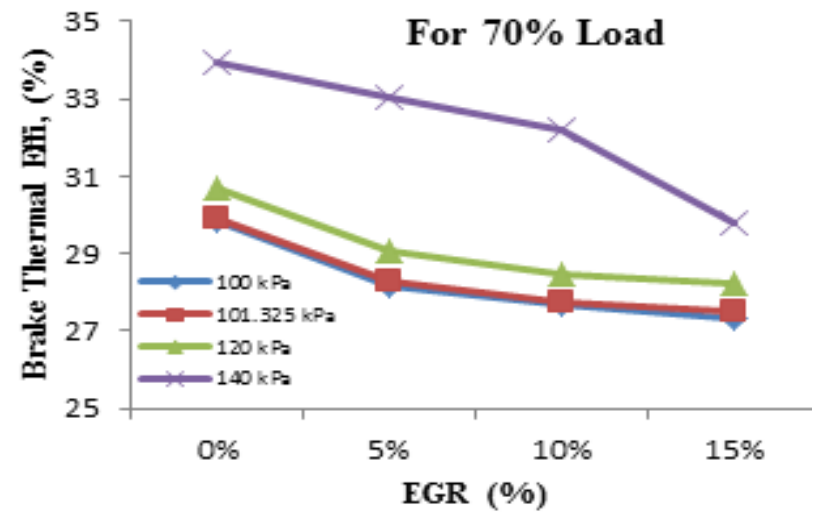

(b)

Figure 5.1 Brake thermal efficiency for different inlet air pressure and EGR rate: (a) at 50\% load, (b) at $70 \%$ load.

Fig. 5.2 (a) and (b) represents comparison of BSFC for all datasets using EGR with inlet air pressure for $50 \%$ and $70 \%$ load condition. The BSFC is clearly a function of AFR as discussed in details by Heywood [19]. The discharge air decreases when the EGR rate increases and increases when inlet air pressure increasing. It was found from the experiment that BSFC is increased with increasing in EGR rate because oxygen available for combustion gets reduced for the amount of fuel supplied. Thus, air fuel ratio is changed and this increases the BSFC. But by increasing inlet air pressure with EGR system, BSFC is decreased because by supplying pressurized inlet air, density of air increased and thus more oxygen available for combustion.

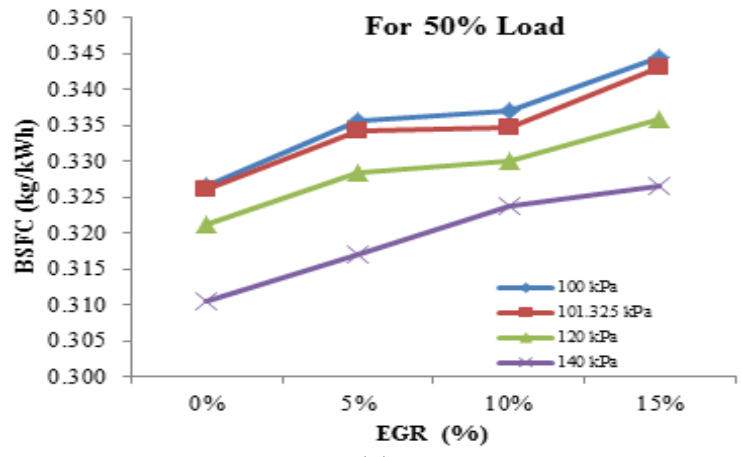

(a)

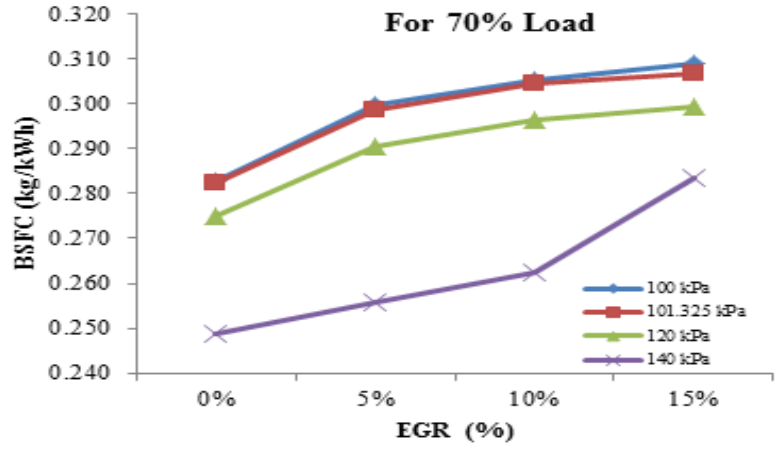

(b)

Figure 5.2 BSFC for different inlet air pressure and EGR rate: (a) at 50\% load, (b) at $70 \%$ load.

Fig. 5.3 (a) and (b) shows the exhaust gas temperature for increasing inlet air pressure and EGR rate at $50 \%$ and $70 \%$ load condition. The exhaust gas temperature decreases more by increasing inlet air pressure with EGR rate. Exhaust gas temperature decreases with increase in EGR rate. The reasons for temperature reduction are relatively lower availability of oxygen for combustion and higher specific heat of intake air mixture as explained earlier. Exhaust gas temperature also decreases with increase in inlet air pressure since advanced 
injection timing at higher inlet air pressure caused low-temperature reaction. In other words, as the inlet air pressure is increased further, cylinder gas temperatures are decreased, allowing more advanced injection timing. Thus by increasing inlet air pressure with EGR system lowered more exhaust gas temperature than individual EGR system.

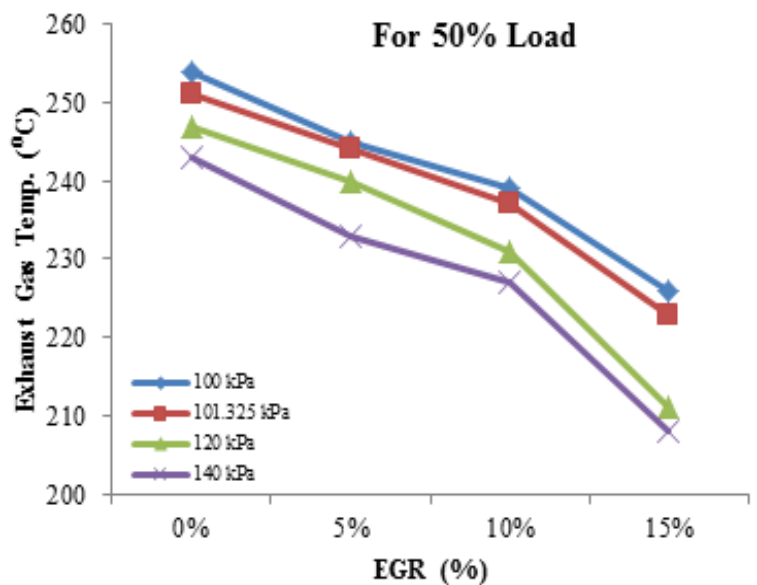

(a)

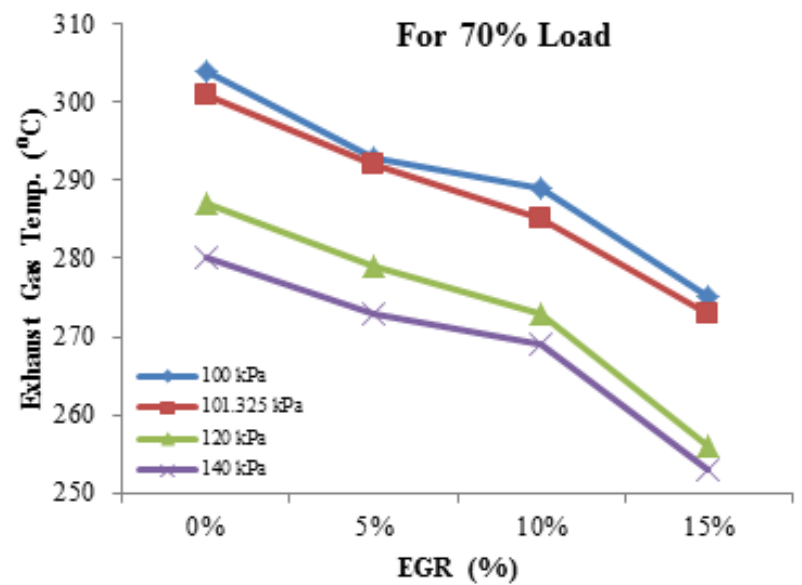

(b)

Figure 5.3 Exhaust gas temperature for different inlet air pressure and EGR rate: (a) at 50\% load, (b) at 70\% load.

\subsection{Engine Emission Analysis}

Fig. 5.4 (a) and (b), Fig. 5.5 (a) and (b) and Fig. 5.6 (a) and (b) shows the trend of hydrocarbons, carbon monoxide and carbon dioxide for combine effect of increasing inlet air pressure attachment and EGR system at $50 \%$ and $70 \%$ loading condition. $\mathrm{HC}, \mathrm{CO}$ and $\mathrm{CO}_{2}$ are the important emissions which forms during the combustion process by depending on the combustion temperature and mixture homogeneousness. These emission decreases with increasing combustion temperature or exhaust gas temperature and vice versa. Mainly low combustion temperature regions such as boundary layer near the cylinder walls cause the formation of these emissions. From the experiment it was found that emission of $\mathrm{HC}, \mathrm{CO}$ and $\mathrm{CO}_{2}$ increased with increasing inlet air pressure and EGR rate, the possible reason may be decrease in combustion temperature or exhaust gas temperature.

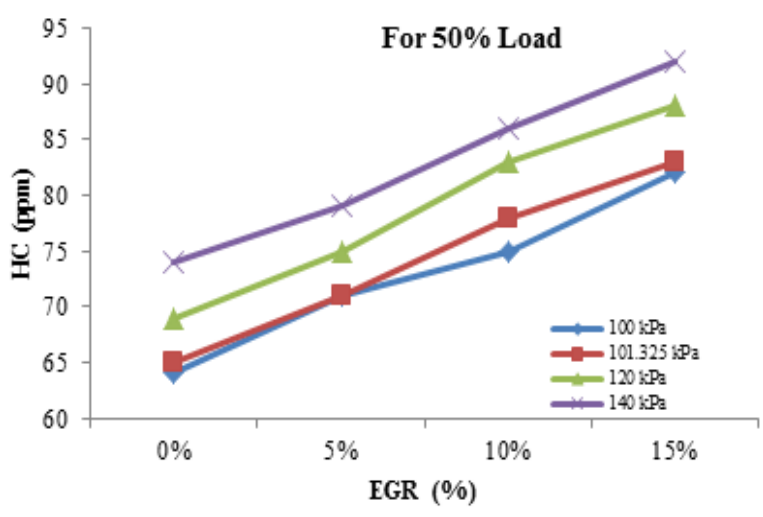

(a)

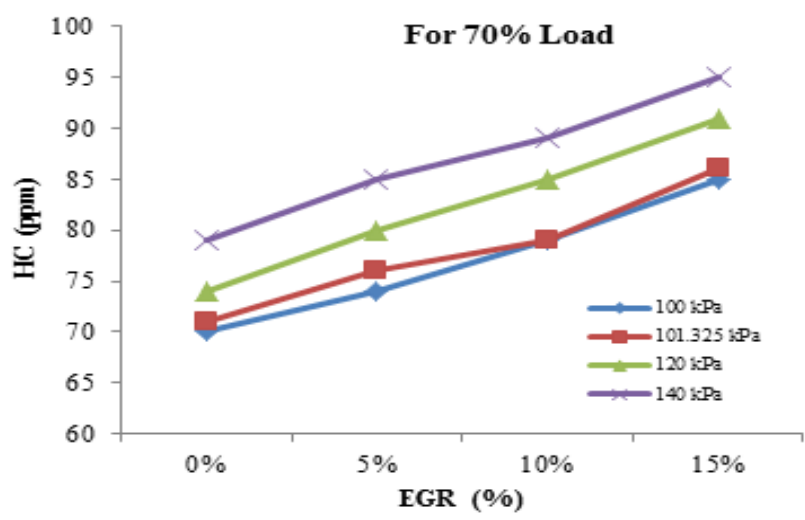

(b)

Figure 5.4 Hydro carbon emission for different inlet air pressure and EGR rate: (a) at 50\% load, (b) at 70\% load 


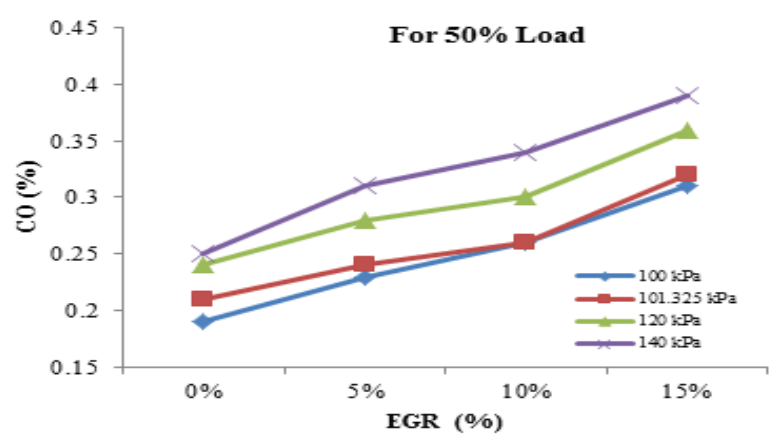

(a)

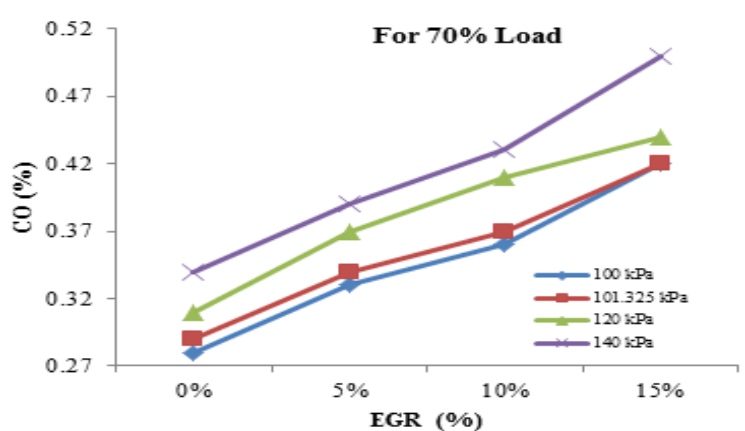

(b)

Figure 5.5 CO emission for different inlet air pressure and EGR rate: (a) at 50\% load, (b) at 70\% load

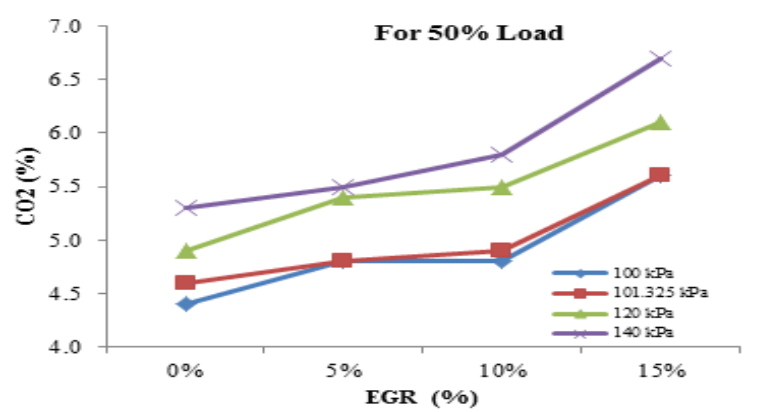

(a)

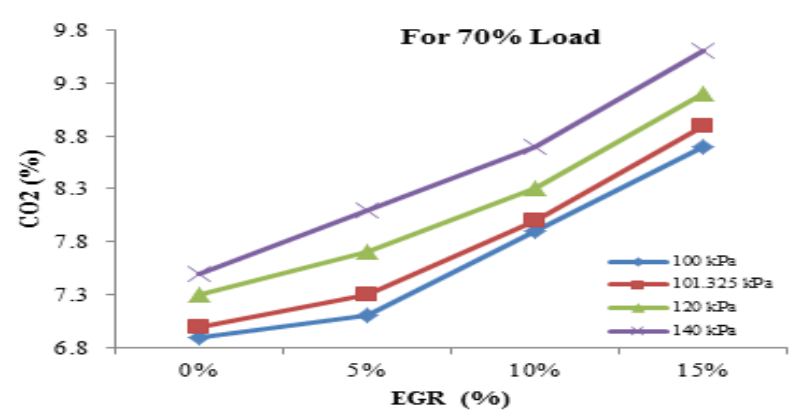

(b)

Figure 5.6 $\mathrm{CO}_{2}$ emission for different inlet air pressure and EGR rate: (a) at 50\% load, (b) at 70\% load

Fig. 5.7 (a) and (b) show the NOx emission as consequence of EGR rate and varying inlet air pressure at 50\% and 70\% load condition. This figure shows main benefit combine effect of EGR and varying inlet air pressure. It is acknowledge that this emission was highly depended on post-combustion gas temperature, duration of gas exposure to this high temperature combustion and the species in post-combustion gases. The function of AFR is also significant to the formations of NOx. The formation of exhaust emissions is strongly dependent on fuel distribution and the rate of change for fuel distributions due to mixing process [20]. The NOx is decreased when the AFR increases as discussed by many authors [13, 19, and 20]. Many researchers agree that the increase of boost pressure promoted to the lean combustions of diesel engine and the rate of heat release is resemble to the injection rate and becomes sharper and the quality of combustion improves [13, 20]. Therefore, pressure rise is proved to gives same results as the boost pressure on engine emissions.

The general trend of the NOx emissions is inversely related to the $\mathrm{HC}, \mathrm{CO}$ and $\mathrm{CO}_{2}$ emissions since NOx is reduced as the combustion temperature decreases. It was found from the experiment that NOx is reduce more by combining EGR rate with increasing inlet air pressure. Because by increasing EGR rate and inlet air pressure it decreases combustion temperature and duration of gas exposure to this high temperature combustion and also increases AFR.

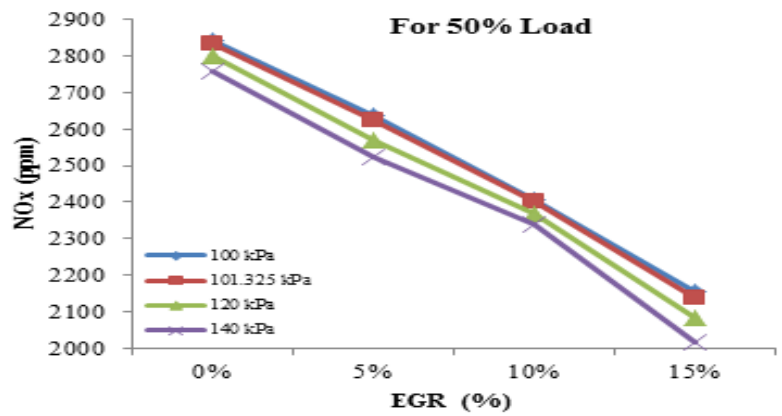

(a)

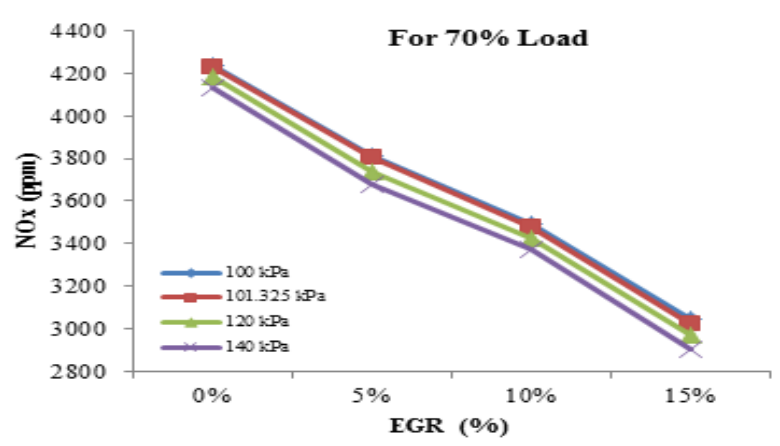

(b)

Figure 5.7 NOx emission for different inlet air pressure and EGR rate: (a) at 50\% load, (b) at 70\% load 


\section{Conclusions:}

An experimental setup was developed to measure the combine effect of increasing inlet air pressure and EGR system on engine performance and emission like brake thermal efficiency, brake specific fuel consumption, $\mathrm{NOx}, \mathrm{CO}, \mathrm{CO}_{2}$ and $\mathrm{HC}$. From the result following conclusion has been derived.

$>$ It was found from the experiment that combined effect of increasing inlet air pressure attachment and EGR system provided better result on engine performance. BSFC decreases and brake thermal efficiency increases by increasing inlet air pressure with EGR system than individual EGR system.

> Combined effect of increasing inlet air pressure attachment and EGR system is also more beneficial way to reduce significantly NOx emission than individual EGR system because NOx is reduced as the combustion temperature decreases.

> The increase in $\mathrm{CO}, \mathrm{HC}$, and $\mathrm{CO}_{2}$ emissions can be reduced by using exhaust after-treatment techniques, such as diesel oxidation catalysts (DOCs) and soot traps.

\section{Acknowledgements}

It is indeed a pleasure for me to express my sincere gratitude to those who have always helped me for this paper. First I thanks to almighty god who gave strength, courage and sense to complete this paper. I am humbly expressing thanks to my respected guide Prof. Gaurav P. Rathod for his valuable time and constant help given to me. He provided me this opportunity to work in this inspiring project. With his enthusiasm, inspiration, and great efforts to explain things clearly and simply, he helped to make this work fun. Throughout he provided encouragement, sound advice, good teaching, good company, and lots of good ideas. I have learned many things from him such as the way of thinking and the way of conducting speech. I wish to express my deep gratitude to Prof. T. M. Patel for their valuable time and constant help. Finally, I am thankful to all the faculty members of Mechanical Engineering Department (LDRP-ITR) and my parents, all my friends who have directly or indirectly helped me during this work.

\section{Research Papers}

\section{References}

[1]. Annual diesel report. <http://www.ricardo.com/pages/diesel report.asp>.

[2]. K.M. Stewart, Health effects of diesel exhaust. Report from American Lung Association of Pennsylvania, 2001.

[3]. Y.A. Levendis, I. Pavlatos, R. Abrams, Control of diesel soot, hydrocarbon and NOx emissions with a particulate trap and EGR, in: SAE 940460, 1994.

[4]. N. Ladommatos, R. Balian, R. Horrocks, L. Cooper, The effect of exhaust gas recirculation on combustion and NOx emissions in a high-speed directinjection diesel engine, in: SAE 960840, 1996.

[5]. S. Sasaki, D. Sawada, T. Ueda, H. Sami, Effect of EGR on direct injection gasoline engine, JSAE Rev. 19 (1998) $223-228$.

[6]. Zelenka P, Aufinger H, Reczek W, Catellieri W. Cooled EGR-a key technology for future efficient HD Diesels. SAE paper 980190, 1998

[7]. Kreso AM, Johnson JH, Gratz LD, Bagley ST, Leddy DG. A study of the effects of exhaust gas recirculation on heavy-duty Diesel engine emissions. SAE paper 981422, 1988.

[8]. J. Kusaka, T. Okamoto, Y. Daisho, R. Kihara, T. Saito, Combustion and exhaust gas emission characteristics of a diesel engine dual-fueled with natural gas, JSAE Rev. 21 (2000) 489-496.

[9]. G.H. Abd-Alla, Using exhaust gas recirculation in internal combustion engines: a review. EnergyConversion and Management 43 (2002) 1027-1042.

[10]. Nidal H. Abu-Hamdeh, Effect of cooling the recirculated exhaust gases on diesel engine emissions. Energy Conversion and Management 44 (2003) 3113-3124.

[11]. Ming Zheng, Graham T. Reader, J. Gary Hawley, Diesel engine exhaust gas recirculation-a review on advanced and novel concepts. Energy Conversion and Management 45 (2004) 883-900.

[12]. Avinash Kumar Agrawal, Shrawan Kumar Singh2, Shailendra Sinha And Mritunjay Kumar Shukla, Effect of EGR on the exhaust gas temperature and exhaust opacity in compression ignition engines. Sadhana Vol. 29, Part 3, June 2004, pp. 275-284

[13]. Colban, W.F., P.C. Miles, and S. Oh, Effect of Intake Pressure on Performance and Emissions in an Automotive Diesel Engine Operating in Low Temperature Combustion Regimes. SAE Technical Paper 2007-01-4063, 2007.

[14]. M.M.Z. Shahadat, M.N. Nabi, M.S. Akhter, M.S.H.K. Tushar, Combined Effect of EGR and Inlet Air Preheating on EnginePerformance in Diesel Engine. International Energy Journal, Volume 9, Issue 2, June 2008.

[15]. Mustafa Canakci, An experimental study for the effects of boost pressure on the performance and exhaust emissions of a DI-HCCI gasoline engine. Fuel 87 (2008) 1503-1514.

[16]. Rizalman Mamat, Nik Rosli Abdullah, Hongming Xu, Miroslaw L. Wyszynski, Athanasios Tsolakis, Effect of Air Intake Pressure Drop on Performance and Emissions of a Diesel Engine Operating with Biodiesel and Ultra Low Sulphur Diesel (ULSD). International Conference on Renewable Energies and Power Quality (ICREPQ'09) Valencia (Spain), 15th to 17th April, 2009.

[17]. Simon Reifarth, EGR-Systems for Diesel Engines, TRITA - MK 2010:01, ISSN1400-1179, ISRN/KTH/MMK/R-10/01-SE.

[18]. Jaffar Hussain , K. Palaniradja, N. Alagumurthi, R. Manimaran, Effect of Exhaust Gas Recirculation (EGR) on Performance and Books Emission characteristics of a Three Cylinder Direct Injection Compression Ignition Engine. Alexandria Engineering Journal (2012).

[19]. Heywood J B 1988 Pollutant formation and control. Internal combustion engine fundamentals Int.edn (New York: Mc-Graw Hill) pp 572-577.

[20]. V.Ganesan, Internal Combustion Engine. 2003, New Delhi: McGraw Hill. 